\title{
The Public Discussion on Flat Earth Movement
}

\section{An Analysis Based on the Esperantist-Epideictic Discourse}

\author{
Cristiano Mattos ${ }^{1,2}$ (D) Felipe Sanches Lopez ${ }^{3}$ (D) . José Luis Ortega ${ }^{4}$ (D) \\ André Rodrigues ${ }^{1}$ iD
}

Accepted: 5 January 2022 / Published online: 29 January 2022

(c) The Author(s), under exclusive licence to Springer Nature B.V. 2022

\begin{abstract}
The paper reflects on public discourses about science and pseudoscience, proposing the same discursive structure for both-the Esperantist-Epideictic genre. This genre of discourse might bring together characteristics that we understand as constituents of the public discourse on science. It also enables us to depict the process by which to maintain cohesion on a group's values. The discursive activity points to science as neutral, free, and independent of social influences captivating those already in this discursive sphere. The discursive hermeticity appears in the Esperantist content and the Epideictic form by avoiding the dialogical situations where there is no epistemological and axiological dispute. We thus show that the Esperantist-Epideictic genre helps to understand the process of maintaining a cohesive group whose beliefs about the Flat Earth appear in social media. We use data from three sources: transcriptions from seminars held at that 1st FlatCon Brazil, most viewed videos on YouTube where affirmationists talk about Flat Earth, and semi-structured exploratory interviews conducted at FlatCon. Our findings indicate that some conceptions of validation of knowledge, scientific method, science bias, reality, and truth compound a distinct part in the current conversations about the Flat Earth movement. Moreover, the Esperantist-Epideictic genre of discourse can be an analytical tool for framing the echo chamber in social media while defending or attacking the Flat Earth movement. We conclude that in a time where there is a growing consensus that science is under attack, the ways in which its defenders are trying to stand up to it may be causing some harm.
\end{abstract}

Keywords Flat earth $\cdot$ Esperantist-epideictic genre $\cdot$ Science $\cdot$ Pseudoscience

\section{Introduction}

Science teachers might occasionally face science denial in classrooms. As Fackler (2021) conjectures, fact confrontation and correction methods might not be enough to impact students' beliefs. The students' initial misconception or beliefs get even stronger as a backfire effect. Additionally, Darner (2019) argues that science denial has been moving from the

Cristiano Mattos

crmattos@usp.br

Extended author information available on the last page of the article 
social periphery to the center and became a "barrier to educating a science-informed citizenry." (p. 229).

Metin et al. (2020) indicated that pseudoscience might be related to the lack of critical thinking and knowledge on the Nature of Science (NOS) (see also, Afonso \& Gilbert, 2010). They also underline that students remain vulnerable to pseudoscientific beliefs and are usually unaware of the commercial intentions on it. Despite the recent effort to grasp this science denialism, pseudoscience phenomena, and its impacts on science classrooms (Barzilai \& Chinn, 2020; Hansson, 2017), current science denial's causes, development, and dynamics remain unclear to science educators.

There is a growing distrust in the institutions and science in the middle of ideological struggles. A comprehensive survey with a sample of 140 mil participants in 140 countries concerning public trust in institutions and science indicates that South America is the region with the highest rate (39\%) of the answering no to the question: "People who think the work scientists do benefits people like them." According to the report, South and Central America are the regions where people tend to be most skeptical about the benefits of science reaching themselves (Gallup, 2019). On the other hand, Gauchat (2012) developed an analysis using a repeated cross-sectional sample from 1974 to 2010 with more than 30,000 cases in the USA. His findings indicate that the public trust in science remains stable throughout time, except among conservative groups and those who frequently attend church.

Additionally, "the analysis provides negligible evidence for the cultural ascendency thesis, which suggests that trust in science will increase over time. Nor do results support the alienation thesis that predicts a uniform decline in public trust in science." (Gauchat, 2012, p. 182) The study brings forward that public trust in science has been changing throughout the years as an arena of political dispute. The findings reinforce the current research that detects an increasing polarization around some scientific topics (Drummond \& Fischhoff, 2017; Kahan et al., 2012; Samantray \& Pin, 2019; Tucker et al., 2018). A deep understanding of the current public trust in science and the aggravation of the polarization seem critical for science educators since they have to put up with such issues daily within the classrooms.

Notions such as post-truth and fake news have gained popularity in modeling distrust and polarization. Barzilai and Chinn (2020) argue that although post-truth is not a new phenomenon, it has been intensified by how information is shared and consumed with social media. According to the authors, some "associate the post-truth condition with the rise of "echo chambers"' (Barzilai \& Chinn, 2020, p. 109), in which the information is produced and shared in restricted circles that reinforces preferences, sentiments, and worldviews. Furthermore, they claim that "Trust in science may also be undermined by science communication practices such as overstating scientific findings or creating a 'false-balance", (Barzilai \& Chinn, 2020, p. 109). At large, the studies have pointed out that the recent processes by which people are producing, sharing, and consuming information in social media play a critical role in spreading misinformation (Samantray \& Pin, 2019; Xu et al., 2021). Vraga and Tully (2021) indicate that those who are likely to share and post misinformation and fake news on social media are precisely those with little knowledge and skills to evaluate the content.

Among all the social media, YouTube has been gaining attention for the intense news circulation-as well as misinformation-and its educational potentialities. In a study on information circulation during the coronavirus outbreak, Khatri et al. (2020) highlight that disseminating information through YouTube has been critical. The study shows that although the popular videos are mostly informative, the misinformation popularity (likes) 
is higher in Mandarin than in English. Ultimately, it indicates that the dissemination of misinformation and science denial might be a cross-cultural phenomenon. According to Allgaier (2019), science denialists (e.g., creationist groups) have explicitly oriented the followers to use YouTube as an effective platform for "internet evangelism" (Allgaier, 2019, p. 11, see also 2013).

One emergent denialist group that is worth examining is the so-called Flat Earth movement. Olshansky et al. (2020), in a study centered on interviews gathered during the 2nd Annual Flat Earth International Conference, mention that this movement is relatively new on the internet and gained attention on YouTube after 2014. According to the authors, it is possible to find a common narrative that alludes to a gradual conversion of people to the Flat Earth movement via YouTube. The study presents a conversion process triggered by videos suggested by YouTube algorithms. It means that the viewers were not actively looking for this type of content. Most of the videos are produced by Flat Earthers that create their own channel and occasionally sell products related to Flat Earth (books, models, art design, etc.). The video contents appeal to science, conspiracy theories, sensorial experiences, and religion - particularly to some trends of the Bible interpretation like Biblical literalism. Although it is possible to identify a sort of religious orientation, the authors point out that not all Flat Earthers are Biblical literalists. As we shall discuss in this paper, the religious nature of the Flat Earth movement remains somehow unresolved-at least from our data in Brazil. Right now, it is hard to determine the reach, sustainability, and concrete impact in science classrooms of such a denialist movement. However, the scrutiny of their discourses, as well as the ways by which they are confronted in the public discussions, might offer relevant insights for science teachers who are willing to approach controversial topics regarding the NOS in the classroom.

This study addresses two research questions:

How is the discussion about the Flat Earth shaped in the public discourse, particularly those in social media like YouTube?

How are notions such as knowledge, scientific method, reality, and truth used in the polarized discussion about the Flat Earth?

We hypothesize that the public discourse around the Flat Earth in social media is reinforced by and a reinforcement of the "echo chamber" for both groups (attacking and defending). Both groups use notions of knowledge, scientific method, reality, and truth as unproblematic and dogmatic. Ultimately, the public discourse about the Flat Earth in social media might be trapped in a sort of discursive mirror, with no gain of understanding for the general public.

We scrutinize how the public discourses about the Flat Earth have been shaped, considering not only the Flat Earthers' (denialists) discursive production but also those in the name of science (affirmationists) that are attacking denialist groups and ideas. We use materials gathered from the 1st Conference for Flat Earthers (FlatCon) in Brazil in 2019 and popular scientific communicators addressing this topic on YouTube. The study aims to provide a frame for understanding, in social media environments, the role public discourse about science plays in educating the public about why and when trust in science is warranted. We present two major findings: first, some aspects related to NOS, such as conceptions of validation of knowledge, scientific method, science bias, reality, and truth, which compound a distinct part in the current conversations about the Flat Earth movement. Second, the Esperantist-Epideictic discourse genre can be an analytical tool for researchers and educators to better understand the "echo chamber" in social media while defending 
or attacking the Flat Earth. Although our study focuses on the public discussions on Flat Earth within this circulation sphere, we reflect on how our findings could help science teachers to reframe the dogmatic view of science when introduced in school (see Izquierdo et al., 2008).

\section{Literature Review}

\subsection{The Shape of the Earth in Science Education Research}

Although we acknowledge that the recent Flat Earth movement does not fully overlap with the children's alternative conceptions on Earth's shape, it shall be helpful to our later reflection on the impacts of science teaching. We will provide a brief overview of what we know about this specific alternative conception, how it has been treated, and what instruments are available to science teachers. Science education research has produced a rich picture of the challenges and potentialities of learning Earth's shape.

Several studies focused on students' conceptions about the shape of the Earth were associated with the efforts of better understanding and mapping the students' alternative conceptions-preconceptions, misconceptions, or mental models (Driver \& Easley, 1978; Gilbert \& Watts, 1983; Hashweh, 1988). While some studies were diagnostic in nature, aiming to identify and systematically map students' conception across age and culture, others look at a more structural explanation for the learning process in the quotidian. In this vein, some seminal research was from the mid-1970s (Nussbaum, 1979; Nussbaum \& Novak, 1976; Sneider \& Pulos, 1983). The studies on alternative conceptions show a variety of sources as daily experiences, poor representations in textbooks, and, more recently, the internet (Sesen \& Ince, 2010; Vojîr \& Rusek, 2019).

Vosniadou and Brewer (1992) report that children and adolescents hold at least six different models, and the majority uses a mixed model in the tasks. The common models used rectangular Earth, disc Earth, dual Earth, hollow sphere, flattened sphere, and sphere. They discuss the difficulties and limits associated with such measurement. In inquiry about similar aspects, Fréde et al. (2011) indicate that the results on students' conception are sensible to the research instrument-open or forced-choice questions. Furthermore, corroborating the findings with British students (Panagiotaki et al., 2009), the study shows that the French student seems to be more knowledgeable almost 20 years later than those presented in Vosniadou and Brewer' study in the US context. Frède et al. (2011) suggested that the result differences could be explained due contextual changes since "today's children are likely to have been exposed to the internet, to more international travel, and to more formal and informal education on subjects that help them understand the Earth, such as global warming." (Frède et al., 2011, pp. 441-442) Although it is reasonable to assume that the internet plays a relevant role in the development of children's alternative conceptions, more research is needed to understand the extension of the influence and the specific mechanisms by which the internet, and for that matter, social media, with children's specific conceptions.

In the 1980 s, one fairly common approach to tackle alternative conceptions and misconceptions was associated with the conceptual change strategies that, in some cases, sought to replace the students' initial conception with the scientific ones (Hewson, 1981; Hewson \& Hamlyn, 1984; Hewson \& Hewson, 1983; Posner et al., 1982). According to Mortimer (1995), despite the variety of theoretical formulations underlining some 
trends in the conceptual change, the researchers and teachers expect students to abandon their initial concepts during the teaching process. Additionally, most of the teaching within conceptual change falls into cognitive conflict and analogy-based strategies.

On the issue of resilient alternative conceptions, Linder (1993), while proposing a social framework for conceptual dispersion, asserts:

The educational problem brought to the fore by the alternative conceptions literature is not, I argue, that students have alternative conceptions or strong highly resistant to change preconceptions: The problem is that many students do not develop new meaningful relationships with the new contexts that they are introduced to within the educational environment. [...] So, instead of depicting meaningful learning in terms of conceptual change we should consider depicting it in terms of conceptual appreciation -- an appreciation that is delimited by context. (Linder, 1993, p. 295, emphasis in original)

He moves from the strong cognitivism emphasis on conceptual change toward a phenomenographic perspective and focuses on the meaningful relations students established with the context.

Moreover, epistemological pluralism has gained some visibility in science teaching, and domains of knowledge appear more regularly in this research field (Chang, 2012; Fackler, 2021; Orduña Picón et al., 2020; Ribeiro \& Pereira, 2013; Southerland $\&$ Scharmann, 2013). Fackler (2021) underlines the potential of understanding knowledge production while avoiding aggravating the science denial in the backfire effect. She suggests a close look "at expanding ways of knowing and marking the boundary between the scientific way of knowing and other ways of knowing at the same time, comparing claims and arguments that derive from different domains of knowledge, recognizing the power and limitations of science, and learning about different ways science is done." (Fackler, 2021, p. 13) According to Southerland and Scharmann (2013), science teachers should address science as a way of knowing while exploring its boundaries, making them more explicit. It is a way to accommodate different perspectives and ways of knowing, such as scientific, artistic, and religious, while providing the students with a place to stand and make personal decisions. Although epistemological pluralism seems directed toward including and dealing with diversity, more research is needed to understand the genesis and development of science denial in society, particularly in classrooms.

\subsection{A Glimpse on the Rise of the Flat Earth}

In its contemporary form, the Flat Earth movement emerged in the middle of the post-truth era, with scientific distrust, conspiracy theories, and religious fundamentalism (McIntyre, 2018). McIntyre (2018) argues that science denial is commonly placed in scientists' possible bias and ideological directivity. However, those who are making use of this argument are far from advocating for ideologically free science. As he states:

The goal here is a cynical attempt to undercut the idea that science is fair and raise doubts that any empirical inquiry can really be value neutral. Once this has been established, it seems a small step to make the case for consideration of "other" theories. After all, if one suspects that all science is biased, it may not seem so egregious 
to consider a theory that might be tainted by one's own ideological beliefs. (McIntyre, 2018, p. 19)

Moreover, he indicates that science denial can start from an economic or ideological agenda. He bonds the current state of science denialism in the USA with how the conservative movement developed in the last 30 years. In the last years, especially in the USA and Brazil, the conservative groups have gained strength and shape based on religious morality as a relevant political banner (Oliveira, 2020; S. Posner, 2020). In this religious and political climate, the Flat Earth movement finds some fertile ground in Brazil and starts national associations and conferences. One key factor in understanding the Flat Earth movement in Brazil lies in its umbilical relationship with movement evangelical fundamentalism, particularly in the USA.

The notion of Flat Earth goes back to ancient civilizations. The models and disputes around the Flat Earth in ancient Greece were tinted with the matters of its time. According to Couprie (2018, p. 19), "When the ancient Greeks said that the earth is flat, they did not mean it literally, because the surface of the earth has mountains and valleys, lakes and seas. More importantly, in Presocratic cosmology, the Flat Earth was usually thought to be somewhat concave." Moreover, "Originally, when everyone was convinced that the earth is flat, there was no need to argue for its shape, but it was only necessary to suggest some modifications, such being slightly concave. But as soon as some cosmologists put forward the idea of a spherical earth, the believers in a Flat Earth needed arguments of their own." (Couprie, 2018, p. 21) The idea of Flat Earth has somehow crossed history entangled with social and religious practices. Throughout the Medieval age, the problems around the shape of the Earth barely touched the minds of Lords and Servants; however, it starts to gain importance during the commercial navigations in the fourteenth and fifteenth centuries. Meanwhile, Christianity, in the form of Biblical literalism, carried the idea through time.

The Flat Earth movement has ties with some trends in the literary interpretations of the Bible as an inerrant sacred text that brings absolute truth and is free of error in its statements. Inerrancy appears as a relevant protestant doctrine (Roberts, 2008). Thus, the Flat Earthers' speeches are commonly based on the literal reading of the biblical text to oppose scientific statements (Olshansky et al., 2020). For this reason, along with the creationists, the Flat Earth idea can be seen as an interesting case of a movement that claims truth based on the Bible. The belief in the Flat Earth may occupy a unique place in the relationship between science and evangelism (Garwood, 2013).

\section{Theoretical Framework}

To frame the public discourse struggles about Flat Earth is necessary to examine the discursive characteristics. Therefore, we ground the study on the concepts of the sphere of circulation of utterances and discursive genre (Bakhtin, 1987) to characterize the sphere of public discourse on science and pseudoscience enunciative forms stabilized in the overlapping of determined social practices. Bakhtin points out that the discursive genres express fields of human activities supported by concrete and coordinated actions, which determine addressing and expectation of response of the discourse.

Furthermore, we propose two dimensions related to the content and form of this discursive genre operating these spheres. To deal with the content dimension, we are based on Gramsci's (1977) reflections on the world's objectivity, and the characterization of 
Esperantism. To the form, second dimension, we take as a base the Epideictic discourse, characterized by preaching specific values and the demonization of contrary ones.

Although the Epideictic discourse is commonly characterized as an Aristotelian discursive genre (Perelman \& Olbrechts-Tyteca, 1973), here we take the genre in the sense of Bakhtin (1987), as described at the beginning of this section-every genre is supported by a concrete activity within a particular sphere of social practices. In this way, the dimensions we bring intend to express a discursive genre, supported by practices, characteristics of social media, which embody a type of public discourse about science and pseudoscience.

\subsection{Gramscian Conception of Science-Esperantism}

The epistemological discussion about the production of knowledge, scientific or not, implies the ontological discussion of the object dialectically to be known (Mattos, Ortega $\&$ Rodrigues, 2021). This perspective, that some call onto-epistemological (Rodrigues et al., 2014), can be identified in Gramsci (1977, p. 1415-1416), which reinforces the historical and dialectic perspective of the subject-object dyad by indicating that "objective always means 'humanly objective', that which can correspond exactly to "historically subjective"" (our translation). In this perspective, the objectivity of an "external world" can only be affirmed from the perspective of human beings, and it becomes subjective, for particular individuals, throughout history through the development of culture. The novelty brought by Gramsci could be found in introducing the concept of cultural hegemony. There, the objective is subjectively appropriated through a process of cultural unification (hegemony), which is produced and reproduced by various mechanisms, determining dominant ideologies at certain epochs in human history.

The Gramscian conception of objective reality goes against metaphysical materialism, for which reality exists regardless of the existence of human beings. For Gramsci (1977), we know reality uniquely and exclusively from the human being's perspective, which takes place in historical development.

Metaphysical realism breaks the subject-object dialectic when it proposes that the reality of the object exists independently of human beings. In the same way, any type of subjectivism also breaks this dialectic by accepting that reality only exists in individuals' consciousness. Gramsci distances himself from these senses of realism and subjectivism by suggesting that what exists is the relation subject-object. Thus, the position we assume in this paper is that reality is sociocultural-historically constructed and that reality is learned and taught through a process of enculturation of both meanings and practices.

Positivism, throughout Western history, can be considered a dominant ideology in the foundation of the natural sciences (Alam, 1978). In this perspective, the concern is to develop research methods that reinforce the senses and formal logical instruments, which would be the expression of scientific rationality. For Gramsci (1977), accepting the objective reality independent of human beings (the foundation of a metaphysics of the object) is accepting one of the forms of religious faith since the existence of an absolute ontology is an undecidable problem. Thus, the objective is what can be produced by the humanworldly experience and determines the objective reality. This objective reality is what can be verified by any human being, whatever their point of view; however, the "objective," "in the end ... it also depends on a specific conception of the world, it is an ideology" (Gramsci, 1977, p. 1456, our translation). After all, every objective statement of science is historical, constructed, and linked to the dominant goals of a given society, which makes them surmountable: 
If scientific truths were definitive, science would cease to exist as it is, as research, as new experiments and scientific activity would be reduced to a disclosure of the already discovered. What is not true, luckily for science. However, if not even scientific truths are definitive and peremptory, also science is a historical category; it is a movement in continuous development (Gramsci, 1977, p. 1456, our translation).

In this way, a "struggle for objectivity is established, in which science uses representations and theories to express itself and representations are human products, historical constructions that arise from scientific, social and political practices" (Semeraro, 2001, p. 99). That struggle has been established throughout history, where distinct views of science were built, such as the "Aryan Science" disseminated and taught in Nazi pre-war Germany (Lopez; Ortega; Mattos, 2020).

\subsection{Scientific Esperantism}

Along with this discussion about of science, Gramsci (1977) coined the term scientific Esperantism ${ }^{1}$ to express how a particular group of people (scientists or not) believe that this science is a universal and neutral language and that through it, humanity could overcome cultural barriers. For scientific Esperantists:

everything that is not expressed in their language is delusion, prejudice, superstition, etc.; they (with a process analogous to that which occurs in the sectarian mentality) transform into moral judgment or psychiatric diagnosis, what should be a mere historical judgment. (Gramsci, 1977, p. 1467, our translation)

Thus, scientific Esperantism is categorized as a sort of dogmatic fanaticism, which can be equated with dogmatic religious fanaticism. The belief that the sciences, as positive and objective knowledge, can solve any problems in the world, consequently improving life in society as a whole, is expressed through a fundamentalist and dogmatic fanaticism.

Faced with scientific Esperantism, understood as a kind of naive dogmatic positivism, Gramsci indicates that non-Esperantism scientists are essential to combat this superficial fanaticism. To Gramsci (1977), they must use the appropriate means to publicize science as a process and no longer allow journalists and self-educators to do this work.

\subsection{The Epideictic Discourse}

The discourse, as an object of study, refers to the field of language studies, whether textual or oratory (De Fina \& Georgakopoulou, 2020). The concept of discursive genre refers to the variety and complexity of the ways in which the linguistic expressions of the modes of human activity are established throughout history (Ortega, 2019; Ortega \& Mattos, 2018). To Bakhtin (1987, p. 79), the "genres are so diverse because they differ depending on the situation, social position, and personal interrelations of the

\footnotetext{
1 The expression means the "follower of Esperanto." "Esperantism is an endeavour to disseminate in the whole world the use of a neutrally human language which, "not imposing itself in the inner life of the peoples and not at all aiming to displace existing national languages', would give men of different nations the possibility of understanding between one another, which could serve as a peace-keeping language of public institutions in those countries where various nations fight one another on account of language, and in which could be published those works which have equal interest for all peoples." (Foster, 1982, p. 89).
} 
participants in the communication." Thus, a distinction between these discursive genres is essential to identify the activities that support them and serve as the discursive position of the subjects that compose them (Bakhtin, 1987). Simultaneously, in dialogue, the different discourses need parameterization of meaning so that the different subjects in dialogue overcome contradictions of meaning. Thus, dialogical interaction is established, based on argumentation, to establish meanings based on guarantees of meaning.

Every discourse has an audience to be addressed, an audience that, even quiet and silent, demands a way discourse should be made. The audience is not a passive listener but an interacting one reflecting on the discourse (Bakhtin, 1987). Then, to know the audience to discourse is fundamental to construct its form, i.e., the specific words to be used, its content, to establish the speaker's argument.

Following Perelman and Olbrechts-Tyteca (1973), the discourses could have three types with different goals each: (i) the deliberative discourse aiming to counsel for the best result; (ii) the legal discourse intending to establish what is just and fair; and (iii) the Epideictic discourse, whose goal is to praise and blame ideas, so the listener can differentiate what is beautiful from what is ugly.

Since ancient Greece, the discourses are conducted intending to be a mere showpiece, and the audience listens to and applauds the speech and goes home. Different from an actual show, where the applause was the consequence of the presenter reaching a theatrical goal, on an Epideictic discourse, the applause is the goal (Perelman \& Olbrechts-Tyteca, 1973). Still, according to the authors, this type of speech was considered degenerate, with no other goal than to improve adherence to what was being said. Thus, unlike the deliberative and judicial genres, which start from controversial theses and divide the audience, which must agree or refute the theses presented by the speaker, the Epideictic (laudatory) discourse implies the search for reinforcing the audience's adhesion around pre-existing values.

Hence, this discursive genre is mainly used to speak to audiences who already believe in the presented arguments and ideas. There is no intention to provoke criticism, educate, or present new ideas; it is just a discourse for values and morals. The audience becomes mere spectators without participation in the discourse. Propagating and disseminating values, the discourses reinforce the social practice that makes the audience (Perelman; Olbrechts-Tyteca, 2005). Hence, the Epideictic genre composes an infinity of genres present in society, such as those used in party meetings, rallies, masses, and propagandas.

When a discourse happens with no opposition, the speech's object easily seems like a universal truth. In an Epideictic discourse, people will often use the idea of a universal order, a nature, or a god sustaining the speech of uncontested truths promoting the values shared in that one specific community. The Epideictic discourse could be associated with a kind of educational discourse, where the teacher's speech in class is rarely contested or understood as controversial. When using an Epideictic discourse, the speaker does not have a counterpoint to what is being said and converts it into universal truths that should be treated as a historical fact (Perelman \& Olbrechts-Tyteca, 1973).

For Perelman and Olbrechts-Tyteca (2005, p. 54), “[...] epideictic oratory forms a central part of the art of persuasion, and the lack of understanding shown toward it results from a false conception of the effects of argumentation," because it is essential to understand that such a speech has the effect of producing in the audience the shift from the central role of the speaker to a "joint role, of a community of values."

In the same line, Assis and Miranda (2015, p. 126) affirm that "the discursive argumentation undertaken in/by the Epideictic discourse aims to intensify, or reinforce, the 
adherence to the values and choices of these actions." To these authors, these values "are anchored ... in scenographies that put an idea or point of view in the foreground, supported by a rhetoric of praise that creates the conditions for the reinforcement and amplification of these values contained in the scene to be able to circulate discursively."

To keep the community united around a constellation of values, the Epideictic discourse oratory "is concerned with praise and blame, his sole concern is with what is beautiful or ugly. It is a question, then, of recognizing values. But in the absence of the concept of value-judgment, and of that of intensity of adherence" (Perelman \& Olbrechts-Tyteca, 1973, p. 48). The maintenance of the separation between the beautiful and the ugly and between the good and the bad reinforces discursive actions related to the support of this set of values. It seems that, most likely, they give conditions to echo chambers to maintain themselves as discursive spheres whose practices they establish in praise of their set of beliefs and the demonization of their opposite. In this sense, it is possible to identify two characteristics in the Epideictic discourse, those that affirm their position (affirmation) and, at the same time, deny the position of the other (denialism).

Thus, with these two theoretical frameworks, we bring two discursive aspects that comprise the form and content of the discourse. We intend to characterize two dimensions of popular discourse on science, the Epideictic and Esperantist dimensions. We hypothesize that both dimensions bring together characteristics that we understand as constituents of the public discourse on science; thus, we characterize a genre with these two dimensions, which we call the Esperantist-Epideictic genre. This genre is an analytical tool to understand the development of public discussion about science and pseudoscience.

\section{Methodology}

Our analysis focuses on the discourse produced about the notion of Flat Earth by both groups, Flat Earthers (science denialists) and those attacking this notion (science affirmationist). ${ }^{2}$ Hence, we gathered data from popular videos on YouTube discussing the Flat Earth movement and Brazil's 1st Conference for Flat Earthers (FlatCon).

\subsection{Data Gathering}

The data came from three sources: (i) transcriptions from nine seminars held at FlatCon Brazil, available on their YouTube channel, (ii) the ten most viewed videos on YouTube where affirmationist attacks the notion of Flat Earth, and (iii) semi-structured interviews conducted at 1st Flat Earth Conference Brazil (FlatCon).

The search for YouTube videos was made using the term "Flat Earth" ("terraplanismo" in Portuguese), and we selected the most viewed. Brazilians made most videos in Portuguese, and only a few were in English. The FlatCon seminars deal with several topics, such as the reasons scientists would have to lie to the public, the history of Flat Earth, and how

\footnotetext{
${ }^{2}$ Despite identifying and recognizing the dual function of affirmation and denial in the Esperantist-Epideictic genre, expressing the praise of the good and the demonization of the bad, in this paper, the denial and affirmation positions were considered in relation with paradigmatic scientific knowledge. Then, the term denialist is used to denote those who deny science and the term affirmationist for those who affirm science. More specifically, we take those who speak in favor of science and opposed to pseudoscience as affirmationist, while those who speak in favor of pseudoscience and opposed to science we call denialists.
} 
Table 1 Type and quantity of data used in the analysis

\begin{tabular}{lll}
\hline Data type & Denialist & Affirmationist \\
\hline YouTube videos & 9 & 10 \\
Interviews & 7 & 1 \\
Total & 16 & 11 \\
\hline
\end{tabular}

science does to manipulate images of the Flat Earth. In addition, the videos on YouTube attacking the notion of Flat Earth came from seven different channels, with the number of subscribers ranging from 95 thousand to over 3 million.

The FlatCon Brazil took place on November 10th, 2019, in São Paulo and aimed to bring together people who believe that the Earth is flat to discuss their hypotheses, ideas, and problems. The interviews represent the initial step of the research, and it was a relevant moment to talk to Flat Earther and insert some of their key arguments into context. At the conference, we conducted exploratory interviews with seven participants who declared themselves to be Flat Earthers and, surprisingly, with one affirmationist who considered himself an "intruder", a "spy." Among the people interviewed, only him, a trained astrophysicist and researcher in the field, had a divergent opinion from the crowd. It is important to underline that the interviews worked as a subsidiary information source to the survey of the most-watched videos on YouTube on the topic. With the interview, we intended to get content and contextual information about Flat Earther's beliefs in the Flat Earth, first contact with the Flat Earth movement, views on religious knowledge, beliefs in absolute truth, biggest criticism of science, and if science was believed to be part of a conspiracy.

Therefore, the corpus consists of the YouTube videos (totalizing over $9 \mathrm{~h}$ of videos) transcribed and the audio-recorded interviews $(1 \mathrm{~h}$ of interviews consisting of around 7.5 thousand words). The google doc automatic speech recognition was used, and forty excerpts were cast and classified into five a posteriori categories. The data sources and structure are presented in Table 1.

Although unexpected, we decided to keep the interview with the affirmationist to triangulate the affirmationist speeches obtained in the YouTube videos. The numerical difference between affirmationists' and denialists' data does not introduce bias. Our analysis seeks to determine the discursive structure and not a comparative accounting between the number of subjects who make affirmation and negationist discourses. The qualitative discursive analysis highlights the qualities of the discourses supporting the proposed discursive genre (Epideictic-Esperantist genre). It shows that the denialists' discursive structure in the videos and interviews could be considered the same found in the affirmationist speeches, even in YouTube videos or the unique affirmationist interviewed.

\subsection{Empirical Categories}

We used thematic analysis to analyze the interviews and excerpts from the videos to compare the selected excerpts. Thematic analysis aims to categorize the data through recognizable themes and patterns (Aronson, 1995). For this, we use one of its forms of categorization, the inductive or data-driven (Boyatzis, 1998). Thematic analysis has three stages: (i) the selection of excerpts according to their importance for research; (ii) themes and codes are developed, which, for our case, we use a mixture of theory-based and inductive 
categories; and (iii) the validation and use of the codes created in the previous stage (Boyatzis, 1998).

They were validated by reviewing the themes by each of the authors, which ensured, to a certain extent, that the categories and their codes more accurately reflect the excerpts selected for the work (Nowell et al., 2017). The utterances were first classified by proximity in their meanings or the use of certain words such as truth, reality, and evidence; then, the categories were named after the central theme from the speeches to convey their topic and meaning quickly. It is important to note that no distinctions were made between the excerpts of denialists and affirmationist, so that, at the end of the process, it was possible to identify that the categories contained excerpts from both groups, then each excerpt is instantiated by its discursive situation.

An acronym with two parameters will be used to identify denialists' (D) and affirmationists' (A) excerpts. The letter will be followed by a number identifying the individuals who are part of the same group (Dn or An), where $n$ is identifying each individual in each group. The same person can appear in more than one video; this distinction will be made in conjunction with the description of the discursive situation.

The excerpts of videos and interviews that comprise the corpus of this work were analyzed in its content and form, considering the enunciation context. In the case of the utterances whose thematic content can be considered Esperantist, we divided the data, a posteriori, into three thematic categories: (i) absolute truth and empiricism; (ii) scientific terms as credibility; (iii) objective reality and knowledge neutrality.

The first theme, absolute truth and empiricism, brings together excerpts about the belief of both groups about the existence of a reality independent of human beings that can be validated and verified through experiments. The second category, scientific terms as credibility, contains statements that use scientific terms without mediation, emptying their meaning and aiming only to validate the argument authoritatively. The third category, objective reality and knowledge neutrality, brings together statements by affirmationist and denialists about the objectivity and concreteness of knowledge, in addition to its neutrality.

On the other hand, when we consider the form of the speech, we identify typically Epideictic characteristics, thus separating the excerpts into two categories: (i) nondebatable, and (ii) blaming and praising.

Because it is an oratory whose objective is to reaffirm a set of ideas as the correct way of thinking, the Epideictic discourse is characterized by blaming and praising. Following Perelman and Olbrechts-Tyteca (2005), the Epideictic discourse is interested in praising and blaming ideas, saying what is beautiful and ugly.

\section{Results}

\subsection{The Discursive Content: Esperantism in the Speeches of the Denialists and Affirmationists}

The affirmationists and denialists' Esperantism can be identified in excerpts where each group's worldviews' fragments are expressed and addressed to a specific audience. We will quote both groups' discourse in this section to evidence how Esperantism is made explicit and propagated to the audience of that speech. The data were separated into the 
categories: absolute truth and empiricism, scientific terms as credibility, and objective reality and knowledge neutrality.

\subsubsection{Absolute Truth and Empiricism}

Both denialists and affirmationists sustain that each one is the one looking for the truth, and further, the truth comes from experiments and observations that are unquestionable. One of the main characteristics of Esperantism is the belief in an absolute truth that, in addition to being independent of the human being, can be accessed through increasingly accurate experiments. They generally disregard the historical development of scientific objects, which now corresponds to the truth itself, as if it were immutable. One of the questions we asked during the interviews at FlatCon Brazil was: "do you believe in an absolute truth?" to which the denialist D1 answers:

Mathematics is the absolute truth. In mathematics, two plus two will never not be four. And it is with that scientific basis, from mathematics, that we use to make curvature tests and prove the Earth is flat and not spherical (D1)

Therefore, for this denialist, the truth can be achieved with the help of mathematical tools used in experiments. The next one is another denialist explaining the objective of FlatCon, defending the Flat Earth as absolute truth:

Our goal here is to present the Flat Earth truth. We know the scientific community has always manifested that Earth is a spinning ball, we questioned that. [...] we believe that, at some point, the truth of Flat Earth will absolutely come up. (D2)

Another denialist (D3) interviewed, that was also asked if he believes in absolute truths, argues that it may not exist. However, his argument is based on "irrefutable empirical evidence" that is impossible to deny the truth:

Well, the absolute truth, no one has it, right? Even I don't have the absolute truth. I have fractions [of the truth], technical, empirical about Earth's shape. So, I'll tell you about the curvature, about the lighthouses, ships' periscope, the Salar de Uyuni, that there is no curvature. I'll tell you about some real topics that are real and irrefutable. Now, absolute [truth] would be me having all Earth's knowledge, and I don't have it. Then, I can't confirm the absolute truth. I wouldn't have it; maybe no human being would be able to have an absolute truth. (D3)

Something interesting to note in the previous excerpt is the term "irrefutable" D3 used; this term appears again in another excerpt, this time by the "spy" affirmationist interviewed during FlatCon Brazil:

I, at least, try not to put anything on images [...] because I have other in loco observations that can satisfy that explanation [...] if the Sun and the Moon are on a plane surface, how come the Sun sets below the horizon? So, there are physical observations that are irrefutable that don't require an astrophysicist to show their model is wrong. (A1)

In a YouTube video where the goal was to discuss themes of denialism, among them the Flat Earth; the affirmationist A2, despite certifying that the truth does not exist in science, assumes the position of the owner of truth since he has a master's degree in physics. Again, 
we see a relationship between absolute truth and experimentation, the latter being how we access the universal reality:

I don't want to be the owner of the truth. Even though I have a title that says I can be the owner of the truth, up to a limit, in terms of quantum mechanics [...] That's because the absolute truth, statistically, in science, doesn't exist. And the absolute truth is taken from experiments and not from interpretations, I mean, not from hypotheses. The absolute truth comes after you confirm or deny your hypothesis, right? It doesn't come from your mental speculation thinking that something is real or not. You have to do an experiment. (A2)

\subsubsection{Scientific Terms as Credibility}

Esperantists use scientific terms to give credibility to their discourse; most of them are used without mediation to establish the bond of guarantee of the discursive argument. The following excerpt is an example, where A3 is talking about gravitation in a video and explaining how satellite images of the spherical Earth are formed:

through the combination of data provided by different sources, local and global, scientists using a scientific methodology analyze these data and convert them into these images you have seen throughout this video. (A3)

"Scientific methodology" was a generic term used in an attempt to explain how scientists treated data. Given the purpose of the video, to explain how we understand gravity to refute the Flat Earth, the term is used only to give credit to the overall argument used. Likewise, denialists D2 also use this form of argumentation:

I am an NLP practitioner. NLP is the scientific methodology that is Neuro-Linguistic Programming. Scientists and researchers from the past $[\ldots]$ conducted a profound study of language and communication and were able to identify that communication $[\ldots]$ works like mental programming in people's mind $[\ldots]$ Knowing that, the system has been using many forms of this programming [...] (D2)

Likewise, the term becomes empty by not presenting aspects of how NLP would be used to carry out such programming. It has no other use in the argument than trying to guarantee credibility.

\subsubsection{Objective Reality and Knowledge Neutrality}

Belief in absolute truth is usually associated with belief in an objective reality. Both are taken as independent of human will and actions, therefore, considered neutral. Both the denialists and affirmationists, each and every one of them, separately, seem to believe that they can see this reality. The excerpts below are answers from a denialist and an affirmationist to the same question: 'do you believe the earth is flat?', during interviews at FlatCon Brazil:

Is not a matter of believing or having faith, it's a matter of knowing the reality. (D2)

or.

Science is a contemplation of events and the attempt to comprehend these events and explain them in a way that, ideally, they can even be translated to a mathematical 
model $[\ldots]$ science doesn't have sex, it doesn't have religion, it doesn't have a race.

(A1)

The two excerpts above show how the advocated knowledge is seen as neutral. An affirmationist could have said D2's statement. In some way, it is said by A1 when he affirms that science is only the contemplation of phenomena, and scientists' job is to look at the evidence, at reality as it is.

\subsection{The Discursive Form: the Epideictic Construction}

Epideictic discourse is a discursive form, the way the content of the discourse is structured, i.e., in what way the themes will be addressed. As we have seen, the main characteristics of Epideictic discourse are to blame and to praise and not to debate. The following excerpts were chosen to express the characteristics of the Epideictic discourse. The categories were named homonymously to the discourse characteristics.

\subsubsection{Blaming and Praising}

As we have seen, in order to keep the community united around a set of values, the Epideictic discourse praises their own ideas and blames those who do not belong to their "discursive community." The discourse sustains the dichotomy between the beautiful and ugly or between the good and bad, reinforcing and supporting their values. The purpose of the discourse is to belittle opposite ideas and exalt their own. Thus, blame and praise are two interconnected characteristics of Epideictic discourse. For instance:

If you look at all Flat Earther's, denialist's channels, all those people who do pseudoscience, all of them are asking people for money. All of them are charging for courses, while we are giving science courses for free [...] (A3)

In this excerpt, A3 seeks to show its audience how the "other side" conducts its activities, charging for courses while they "are giving science courses for free." In another video, the same A3, reacting to a denialists' video publicizing the creation of an independent research center, praises science, particularly its method:

Also, she [the woman on the video A3 is analyzing] says that they don't need to satisfy anyone, that's the opposite. Science's idea is actually to satisfy someone so that people can critique your work and have the chance to agree, corroborate, refute, comment on what you found or what you published. (A3)

In a moment of discussion with affirmationist, a denialist compares science to the Catholic Church, in reference to the Protestant Reformation, which brought the possibility of questioning the dogmas imposed by a group that controlled the worldview of the period:

Science, not to put it down, but when you're talking about rocket science. This is very difficult for the majority of people to understand, and it's designed that way. And so, in many ways, hiding behind rocket science is similar to religion. If you look at the Catholic Church back in the days [saying] 'only we can interpret the Bible, you have to listen to what we say' [...] we're getting that same notion from science that says 'only we can interpret what these numbers are, you just need to trust us'. (D4) 


\subsubsection{Non-debatable}

The category that contains the most intriguing science's popularization discourse form is the non-debatable. The affirmationists' speeches focus on the impossibility of debates and conversations with Flat Earthers, while the denialists' speeches are about how this attitude reinforces the idea of scientific conspiracy. Perhaps one of the most striking features of the Epideictic discourse, considering the praise and blame characteristic, is to not enter debates. Thus, the speech does not need elaborate guarantees since it is addressed to the public already adept at ideas:

Let me just answer [viewer's name] he said: 'what about inviting a Flat Earther to a debate? It would be interesting [to invite] one that knows something about physics.' If someone knows anything about physics, they're not Flat Earth... It's that simple. And we cannot debate it. Debating means what? There is an idea, that idea could be good, or it could be bad, then there is a debate. Flat Earth does not exist; then, there is no debate. Because at the moment someone knows the minimum, the minimum about physics, they're not Flat Earthers. (A3)

The characteristic of "not debating" is also supported by the Esperantist position, since when one is on the side of absolute truth or objective reality, there is no need to discuss; their way of thinking also becomes absolute, unquestionable. This characteristic is shared with other affirmationists:

[About being called to debate with a Flat Earther] I refused; actually, I just pretended the email didn't exist; I deleted it completely. Because I'm not giving it a spotlight, you know? To those kinds of things like it was something that deserves it [...] Proving the Earth is spherical that it has the shape it has... It's not something that I'll do in a livestream; it's not something that I'll simply say it is [...] (A2)

and:

I don't like debating people because in a debate, what is the construct? It's typically two people, and there's an audience, and you debate some opposite sides of some issue. [...] So, I will not enter a debate where I have the objective truth side of an argument, and the other person does not. That is something that should not be debated, does not belong in front of an audience getting debated. (A4)

It is interesting to note that, considering the data analyzed in this work, which are part of this category, only affirmationists have statements against debate. On the contrary, denialists take a stand against this attitude of affirmationists, taking it as further evidence that "something" is hiding in traditional science:

Then actually, only this elite of people that supposedly have access to it (that would be outer space). So, that we should believe them; it's like having faith. (D5)

The reasons for the lack of debate can be the most diverse, with each affirmationist having his own reason for not wanting to debate. In fact, disdain for the idea is evident in some passages, such as the A4 saying I have the objective truth side of an argument, or the A3 saying that it should not be debated if it does not exist. 


\section{Discussion}

\subsection{Public Discussion and NOS}

Despite any particular argument on Earth's shape, the elements around NOS appear to play a relevant role in the Flat Earth public discourse. Thus, we focused on this aspect to make sense of what is going on in the public discourse on science, pseudoscience, and science denial. We have analyzed the discourses produced and shared by Flat Earthers and those engaged in scientific dissemination and, particularly, in debunking such narrative. This approach provides a sense of how the Flat Earth movement and science denial function while considering what is provided as a counterpart narrative. Although concepts like post-truth and fake news become buzzwords to describe the current science denial wave, they have little power to address the particular mechanisms by which the public discourses operate regarding both levels of content and form.

Moreover, as presented in the excerpts, the discursive substance of science denial seems to be more nuanced, complicated, and diffuse than initially expected. Unlike what can be found in discourses on climate change denialism, there is a distrust in many levels (e.g., global warming, human causes, and the urgency of the problem). Still, there is no consistent effort to provide a counter-narrative or a model. The Flat Earth movement seems more committed to articulating a community around a supposedly competitive model. In this sense, they would be closer to movements like creationists than climate change denialists. The discourse about religion seems somehow unresolved-as a point of tension. In some cases, the discourse of Flat Earthers denies the religious nature of the movement and arguments and uses religion to attack science - considered a church while using Bible quotes and analogies to justify the statements. Moreover, the Flat Earthers, in the production of its discourse, attempt to deny specific scientific facts like the shape of the Earth, some astronomical concepts, and gravitation, while keeping what they see as a general infrastructure of the science such as the scientific method, direct observation, and experimentation.

Although we would characterize the Flat Earth movement as a pseudoscience or science denial movement, the discursive analysis indicates a dispute of an Esperantist version of science. They usually claim the correct and unbiased science, the scientific method, and the truth. Unfortunately, as far as our data can show, the science affirmationists on YouTube are engaged in very similar disputes and claims - for an Esperantist version of science. Despite the general concern regarding a relativist perspective on science in the public discourse, our findings indicated that the circulation and narrative dispute move toward a somewhat different place. Both groups, denialists and affirmationists, claim the simplest and unquestionable absolute truth. There is no attempt to relativize or problematize the notion of truth. On the contrary, the discursive disputes take place within two dogmatic views on science.

The popular discursive dispute around Flat Earth and the NOS through concepts like truth and scientific methods unfolds in ways we perceive as shallow and simplistic. Mainly the discourse disseminated by the affirmationists is much like those of denialists in which the truth is simple, absolute, and empirically warranted. Although our study is not intended to be comprehensive of the internet discourse, the generalizations should be made cautiously. There is value in examining popular videos and discourse related to scientific dissemination. Despite any excellent material one may find on the edges of the internet, the popular discourse, like those we have gathered and examined, might be more likely to affect students' and teachers' perceptions. 


\subsection{Esperantist-Epideictic Genre, “Echo Chamber," Distrust, and Dispute}

In our findings, the analysis through the Esperantist-Epideictic discourse genre enables us to identify the attempts from both affirmationists and denialists to consolidate a community of value around an Esperantist view of science. Thus, the main feature of the EsperantistEpideictic discourse genre about the Flat Earth public discussions is disseminating ideas and values for a captive audience. It also enables us to connect our analysis with the resonance of values and ideas within specific groups working as an echo chamber (Barzilai $\&$ Chinn, 2020) for both denialist and affirmationist Esperantists. This discursive process works as a group bounding element sustained by defending and attacking, praising, and blaming.

The Esperantist-Epideictic discourse genre can provide an analytical frame to make explicit the similarities of what appear to be radically different groups. While discursively addressing some elements of NOS, the science is taken uncritically and ahistorically. Therefore, the notions of validity, warranty, and truth are constantly flowing in mid-air without criticism, neither on the science development nor the relations of science, technology, and society. Most science educators and researchers would expect this perspective in the discourse of Flat Earthers (and deniers in general), but our findings indicate that it is a common discursive genre within the science affirmationist groups' discourse on YouTube.

Although a more detailed study is needed to deeper understand this process, some hypotheses can be proposed for the possible reasons for refusing the debate. One, for example, refers to the YouTube algorithm since the videos recommended for a user are based on their activity on the platform (Alfano et al., 2020). Thus, to disseminate his theme more, the channel owner should produce audience-related content to add more followers, an audience that already has sympathy for the theme. Another way to expand the audience is to include his channel in bigger channels, bringing greater visibility and improving its performance. When choosing and analyzing the most viewed videos on the topic, it is likely that their owners have dissemination strategies that seek not to give visibility to channels with themes contrary to their own, that is, avoiding the debate not to increase the visibility of channels that disseminate denialism.

The second hypothesis is related to science social status. Science already has its hegemony, defended by part of the population and financially supported by Governments. In this way, people who publicize science seem to dispense with the debates to expose their opinion and add followers, giving visibility to the opposing ideas only through their denial. This is not the case with pseudoscience, which has tried to oppose science and achieve its hegemony. The debate of their ideas would help to consolidate them in front of a larger audience.

Then, despite the results of our investigation, further investigations will be needed to more clearly determine the discursive differences, for example, between deniers and pseudoscientists. In addition, the analysis carried out can be extended to other issues in dispute of affirmationist and denialist narratives about, for instance, climate change or mass vaccination.

\subsection{Some Remarks on Science Teaching and School Practice}

Considering the discussion on the role social media environments play in educating the public about why and when trust in science is warranted, we should take into account that the ways of thinking about the Flat Earth do not disappear easily (Frède et al., 2011; 
Mortimer, 1995; Vosniadou \& Brewer, 1992). This occurs, especially when we consider that a significant number of people establish personal epistemologies based on the immediate and particular perceptions of their daily life and reinforced by echo chambers validating their perceptions. On the other hand, the most immediate phenomena that reveal the Earth's sphericity are rare, making teaching and learning of it as tricky as invisible objects, such as molecules or atoms. The occasional absence of social practices demanding the concept of spherical Earth makes it an unusual mediator instrument, unlike the more immediate sensations of everyday life that are strengthened in the quotidian social practices in which the subjects are involved.

The physical phenomena are not evident to the immediate look; understanding their physical meaning is necessary to form a complex net of mediations. The meaning-making comes from knowledge production throughout the history of science; a knowledge stabilized around science community consensus. Thus, science teaching that disregards the conditions of science's cultural and historical production ends up becoming teaching of scientific jargon, which separates itself from the more immediate life of students. On the other hand, considering the predominant banking science teaching model, typically in teachercentered class, science teaching discourse seems to be primarily based on the EsperantistEpideictic genre, in which a supposed superiority of science has validated its knowledge as truth and the scientist as a genius and individual science producer.

The problem that accompanies the Esperantist-Epideictic genre is that Engeström (1991, p. 243) calls "encapsulation of school learning," expressing the school isolation from the students' lives. One consequence of this problem is that scientific knowledge starts to be taught and learned as a syntax without semantics (Ortega \& Mattos, 2018). This phenomenon expands beyond the school curriculum, as school assessments themselves follow patterns of mass assessments, pointing to the idea of a universal science alien to the students' most immediate problems and contexts. Another consequence is that science starts to be consumed as a finished product in the mercantile sphere, in a utilitarian perspective (Rodrigues, Camillo \& Mattos, 2021).

The science taught just as a product has been losing ground sharply to religious and pseudoscientific perspectives, mainly due to the abandonment of the necessary relationships with people's lives. Duschl (2020) recently pointed to the challenges of science education in a post-truth world:

... involve figuring out how to mediate, progress, and coordinate language and knowledge acquisition in the various domain-specific epistemic and social practices of the sciences. The problem is principally about the curriculum and how the curriculum contexts align with both instruction and assessment to facilitate teachers' agency to provide feedback, in turn, to enhance students' agency (Duschl, 2020, p. 189)

Thus, the absence of an immediate context, social practices, and teaching that considers the historical dynamics of scientific production reinforces a NOS that, associated with an Esperantist-Epideictic discursive genre, competes with the forms of religious or pseudoscientific teaching. 


\section{Final Considerations}

In a time where there is a growing consensus that science is under attack, the ways in which science defenders are trying to stand up to it may be causing some harm as well. The Esperantist-Epideictic discursive genre is commonly used to blame and belittle the opposing idea and to praise and ennoble the defending one that might have a reinforcement effect on the public. However, in such conditions, the affirmationists' discourse on a layperson or someone who already tends to believe in conspiracies might have an inverse effect-a backfire effect (Fackler, 2021). As it appears in many statements from denialists, the way affirmationists express their concern, underrate their ideas, or refuse to talk about it is evidence for the denialists that they are on the right path.

Funding Felipe Lopez thanks the research grant 2019/27054-0, São Paulo Research Foundation (FAPESP); Cristiano Mattos thanks Conselho Nacional de Desenvolvimento Científico e Tecnológico (CNPq grant \#302100/2019-9 and \#434918/2018-0).

Data Availability Not applicable.

Code Availability Not applicable.

\section{Declarations}

Ethics Approval and Consent to Participate Not applicable.

Consent for Publication Not applicable.

Conflict of Interest There is no conflict of interest.

\section{References}

Afonso, A. S., \& Gilbert, J. K. (2010). Pseudo-science: A meaningful context for assessing nature of science. International Journal of Science Education, 32(3), 329-348. https://doi.org/10.1080/09500 690903055758

Alam, M. A. (1978). Critique of positivism in the natural sciences. Social Scientist, 6(9), 67-78.

Alfano, M., Fard, A. E., Carter, J. A., Clutton, P., \& Klein, C. (2020). Technologically scaffolded atypical cognition: The case of YouTube's recommender system. Synthese. https://doi.org/10.1007/ s11229-020-02724-X

Allgaier, J. (2013). On the shoulders of YouTube: Science in music videos. Science Communication, 35(2), 266-275. https://doi.org/10.1177/1075547012454949

Allgaier, J. (2019). Science and environmental communication on YouTube: Strategically distorted communications in online videos on climate change and climate engineering. Frontiers in Communication, 4, 36. https://doi.org/10.3389/fcomm.2019.00036

Aronson, J. (1995). A pragmatic view of thematic analysis. The Qualitative Report. https://doi.org/10. 46743/2160-3715/1995.2069

Assis, A., \& Miranda, C. (2015). O Epidítico e(m) cenas da enunciação: a amplificação do discurso organizacional em publicidades [Epideitic and/in enonciation scene: the amplification of organizational discourse in advertisements]. Domínios de Lingu@gem, 9(3), 120-136. https://doi.org/10.14393/DL19v9n3a2015-7

Bakhtin, M. (1987). Speech genres and other late essays (2nd ed.). University of Texas. 
Barzilai, S., \& Chinn, C. A. (2020). A review of educational responses to the "post-truth" condition: Four lenses on "post-truth" problems. Educational Psychologist, 55(3), 107-119. https://doi.org/10.1080/ 00461520.2020 .1786388

Boyatzis, R. E. (1998). Transforming qualitative information: Thematic analysis and code development. Sage Publications.

Chang, H. (2012). Is water H2O? (Vol. 293). Springer Netherlands. https://doi.org/10.1007/ 978-94-007-3932-1

Couprie, D. L. (2018). When the Earth was flat: Studies in ancient Greek and Chinese cosmology. Springer International Publishing. https://doi.org/10.1007/978-3-319-97052-3

Darner, R. (2019). How can educators confront science denial? Educational Researcher, 48(4), $229-238$. https://doi.org/10.3102/0013189X19849415

De Fina, A. \& Georgakopoulou, A. (2020) Rethinking narrative: Tellers, tales and identities in contemporary worlds. In A. De Fina, \& A. Georgakopoulou (Eds.), The Cambridge handbook of discourse studies (pp. 213-234). (Cambridge Handbooks in Language and Linguistics). Cambridge University Press. https://doi.org/10.1017/9781108348195.011

Driver, R., \& Easley, J. (1978). Pupils and paradigms: A review of literature related to concept development in adolescent science students. Studies in Science Education, 5(1), 61-84. https://doi.org/10. 1080/03057267808559857

Drummond, C., \& Fischhoff, B. (2017). Individuals with greater science literacy and education have more polarized beliefs on controversial science topics. Proceedings of the National Academy of Sciences, 114(36), 9587-9592. https://doi.org/10.1073/pnas.1704882114

Duschl, R. A. (2020). Practical reasoning and decision making in science: Struggles for truth. Educational Psychologist, 55(3), 187-192. https://doi.org/10.1080/00461520.2020.1784735

Engeström, Y. (1991). Non scolae sed vitae discimus: Toward overcoming the encapsulation of school learning. Learning and Instruction, 1(3), 243-259. https://doi.org/10.1016/0959-4752(91)90006-T

Fackler, A. (2021). When science denial meets epistemic understanding: Fostering a research agenda for science education. Science \& Education. https://doi.org/10.1007/s11191-021-00198-y

Frède, V., Nobes, G., Frappart, S., Panagiotaki, G., Troadec, B., \& Martin, A. (2011). The acquisition of scientific knowledge: The influence of methods of questioning and analysis on the interpretation of children's conceptions of the earth. Infant and Child Development, 20(6), 432-448. https://doi.org/ 10.1002/icd.730

Gallup. (2019). Wellcome global monitor-First wave findings. https://wellcome.org/reports/wellcomeglobal-monitor/2018

Garwood, C. (2013). Flat earth: The history of an infamous idea. St. Martin's Press.

Gauchat, G. (2012). Politicization of science in the public sphere: A study of public trust in the United States, 1974 to 2010. American Sociological Review, 77(2), 167-187. https://doi.org/10.1177/ 0003122412438225

Gilbert, J. K., \& Watts, D. M. (1983). Concepts, misconceptions and alternative conceptions: Changing perspectives in science education. Studies in Science Education, 10(1), 61-98. https://doi.org/10. 1080/03057268308559905

Gramsci, A. (1977). Quaderni del Carcere (VI-XI; 2nd ed., Vol. 2). Giulio Einaudi.

Hansson, S. O. (2017). Science denial as a form of pseudoscience. Studies in History and Philosophy of Science Part A, 63, 39-47. https://doi.org/10.1016/j.shpsa.2017.05.002

Hashweh, M. (1988). Descriptive studies of students' conceptions in science. Journal of Research in Science Teaching, 25(2), 121-134. https://doi.org/10.1002/tea.3660250204

Hewson, M. G., \& Hewson, P. W. (1983). Effect of instruction using students' prior knowledge and conceptual change strategies on science learning. Journal of Research in Science Teaching, 20(8), 731-743. https://doi.org/10.1002/tea.3660200804

Hewson, M. G., \& Hamlyn, J. (1984). The influence of intellectual environment on conceptions of heat. European Journal of Science Education, 6, 245-262.

Hewson, P. W. (1981). A conceptual change approach to learning science. European Journal of Science Education, 3, 383-396.

Izquierdo, M., Marquez, C., \& Gouvea, G. (2008). A proposal for textbooks analysis: Rhetorical structures. Science Education International, 19(2), 209-218.

Kahan, D. M., Peters, E., Wittlin, M., Slovic, P., Ouellette, L. L., Braman, D., \& Mandel, G. (2012). The polarizing impact of science literacy and numeracy on perceived climate change risks. Nature Climate Change, 2(10), 732-735. https://doi.org/10.1038/nclimate1547

Khatri, P., Singh, S. R., Belani, N. K., Yeong, Y. L., Lohan, R., Lim, Y. W., \& Teo, W. Z. (2020). YouTube as source of information on 2019 novel coronavirus outbreak: A cross sectional study of 
English and Mandarin content. Travel Medicine and Infectious Disease, 35, 101636. https://doi.org/ 10.1016/j.tmaid.2020.101636

Linder, C. J. (1993). A challenge to conceptual change. Science Education, 77, 293-300.

Lopez, F. S., Ortega, J. L. N. A., \& Mattos, C. (2020). Ensino de Ciências como Controle do Estado: o Caso da Alemanha Nazista [Science Education as State Control: the Case of Nazi Germany]. Ensaio Pesquisa em Educação em Ciências (Belo Horizonte), 22, e19654. https://doi.org/10.1590/ 21172020210126

Mattos, C.R.; Ortega, J.L.; Rodrigues, A.M. (2021) Conceptual complexification as an onto-epistemological synthesis in Science Education activity. Submitted.

McIntyre, L. C. (2018). Post-truth. MIT Press.

Metin, D., Cakiroglu, J., \& Leblebicioglu, G. (2020). Perceptions of eighth graders concerning the aim, effectiveness, and scientific basis of pseudoscience: The case of crystal healing. Research in Science Education, 50(1), 175-202. https://doi.org/10.1007/s11165-017-9685-4

Mortimer, E. (1995). Conceptual change or conceptual profile change? Science \& Education, 4(1), $267-285$.

Nowell, L. S., Norris, J. M., White, D. E., \& Moules, N. J. (2017). Thematic analysis: Striving to meet the trustworthiness criteria. International Journal of Qualitative Methods, 16(1), 1609406917733847. https://doi.org/10.1177/1609406917733847

Nussbaum, J. (1979). Children's conceptions of the earth as a cosmic body: A cross age study. Science Education, 63(1), 83-93. https://doi.org/10.1002/sce.3730630113

Nussbaum, J., \& Novak, J. D. (1976). An assessment of children's concepts of the earth utilizing structured interviews. Science Education, 60(4), 535-550. https://doi.org/10.1002/sce.3730600414

Oliveira, F. F. (2020). Governo Bolsonaro e o apoio religioso como bandeira política [Bolsonaro's Administration and religious support as a political flag]. Revista Brasileira de História Das Religiões, 13(37). https://doi.org/10.4025/rbhranpuh.v13i37.52231

Olshansky, A., Peaslee, R. M., \& Landrum, A. R. (2020). Flat-smacked! Converting to flat eartherism. Journal of Media and Religion, 19(2), 46-59. https://doi.org/10.1080/15348423.2020.1774257

Orduña Picón, R., Sevian, H., \& Mortimer, E. F. (2020). Conceptual profile of substance: Representing heterogeneity of thinking in chemistry classrooms. Science \& Education, 29(5), 1317-1360. https:// doi.org/10.1007/s11191-020-00152-4

Ortega, J. L., \& Mattos, C. (2018). The hypertrophy of a physics teaching genre: Aspects of syntax and semantics in the production of scientific concepts. In M. Campos \& G. Souza (Ed.), Media, discourse and teaching. São Paulo, SP: Fflch/Usp. https://doi.org/10.11606/9788575063255

Ortega, J. L. (2019). Contribuições para a teoria e a prática no ensino de física na perspectiva do gênero-atividade [Contributions to the theory and practice of teaching physics from the perspective of genre-activity] [Thesis (Doctorate in Science Education)]. University of São Paulo.

Panagiotaki, G., Nobes, G., \& Potton, A. (2009). Mental models and other misconceptions in children's understanding of the earth. Journal of Experimental Child Psychology, 104(1), 52-67. https://doi. org/10.1016/j.jecp.2008.10.003

Perelman, C., \& Olbrechts-Tyteca, L. (1973). The new rhetoric: A treatise on argumentation (J. Wilkinson \& P. Weaver, Trans.). University of Notre Dame Press. https://doi.org/10.2307/j.ctvpj74xx

Posner, G. J., Hewson, P. W., \& Gertzog, W. A. (1982). Accommodation of a scientific conception: Toward a theory of conceptual change. Science Education, 66(2), 211-227.

Posner, S. (2020). Unholy: Why white evangelicals worship at the altar of Donald Trump. Random House.

Ribeiro, M. A. P., \& Pereira, D. C. (2013). Constitutive pluralism of chemistry: Thought planning, curriculum, epistemological and didactic orientations. Science \& Education, 22(7), 1809-1837. https://doi.org/10.1007/s11191-011-9434-4

Roberts, M. (2008). Evangelicals and science. Greenwood Press.

Rodrigues, A., Camillo, J., \& Mattos, C. (2014). Quasi-appropriation of dialectical materialism: A critical reading of Marxism in Vygotskian approaches to cultural studies in science education. Cultural Studies of Science Education, 9(3), 583-589. https://doi.org/10.1007/s11422-014-9570-7

Samantray, A., \& Pin, P. (2019). Credibility of climate change denial in social media. Palgrave Communications, 5(1), 127. https://doi.org/10.1057/s41599-019-0344-4

Semeraro, G. (2001). Anotações para uma teoria do conhecimento em Gramsci [Notes for a theory of the knowledge in Gramsci]. Revista Brasileira De Educação, 16, 95-104. https://doi.org/10.1590/ S1413-24782001000100010

Sesen, B. A., \& Ince, E. (2010). Internet as a source of misconception: "Radiation and radioactivity." The Turkish Online Journal of Educational Technology, 9(4), 94-100. 
Sneider, G., \& Pulos, S. (1983). Children's cosmographies: Understanding the earth's shape and gravity. Science Education, 67(2), 205-221. https://doi.org/10.1002/sce.3730670209

Southerland, S. A., \& Scharmann, L. C. (2013). Acknowledging the religious beliefs students bring into the science classroom: Using the bounded nature of science. Theory into Practice, 52(1), 59-65. https://doi.org/10.1080/07351690.2013.743778

Tucker, J., Guess, A., Barbera, P., Vaccari, C., Siegel, A., Sanovich, S., Stukal, D., \& Nyhan, B. (2018). Social media, political polarization, and political disinformation: A review of the scientific literature. SSRN Electronic Journal. https://doi.org/10.2139/ssrn.3144139

Vojír, K., \& Rusek, M. (2019). Science education textbook research trends: A systematic literature review. International Journal of Science Education, 41(11), 1496-1516. https://doi.org/10.1080/ 09500693.2019.1613584

Vosniadou, S., \& Brewer, W. F. (1992). Mental models of the earth: A study of conceptual change in childhood. Cognitive Psychology, 24(4), 535-585. https://doi.org/10.1016/0010-0285(92)90018-W

Vraga, E. K., \& Tully, M. (2021). News literacy, social media behaviors, and skepticism toward information on social media. Information, Communication \& Society, 24(2), 150-166. https://doi.org/10. 1080/1369118X.2019.1637445

Xu, Q., Song, Y., Yu, N., \& Chen, S. (2021). Are you passing along something true or false? Dissemination of social media messages about genetically modified organisms. Public Understanding of Science, 30(3), 285-301. https://doi.org/10.1177/0963662520966745

Publisher's Note Springer Nature remains neutral with regard to jurisdictional claims in published maps and institutional affiliations.

\section{Authors and Affiliations}

\section{Cristiano Mattos ${ }^{1,2}$ (D) Felipe Sanches Lopez ${ }^{3}$ [D . José Luis Ortega ${ }^{4}$ (D) . André Rodrigues ${ }^{1}$ iD}

Felipe Sanches Lopez

felipe.sanches.lopez@usp.br

José Luis Ortega

jose.ortega@colband.com.br

André Rodrigues

rodrigues.am@usp.br

1 Institute of Physics, University of São Paulo, São Paulo, Brazil

2 Institute of Physics, University of São Paulo, Rua Do Matão 1371, Cidade Universitária, São Paulo 05508-090, Brazil

3 Science Teaching Interunit Graduate Program, University of São Paulo, São Paulo, Brazil

4 Bandeirantes School, São Paulo, Brazil 